London : D.S.I.R., Lending Library Unit, 1959), the titles being arranged mainly in alphabotical order, using the Cyrillic alphabet. There is also a short list of serials received from Latvia, Lithuania and Estonia, published in the Roman alphabet. Besides an index of transliterated abbreviations of titles, arranged alphabetically, there is an alphabetical subject-list based on a broad framework of the Universal Decimal Classification. The items listed can be obtained by approved borrowers from the Science Museum Library, using loan requisition forms issued by that Library, but these should be sent direct to the Unit at 20 Chester Terrace, London, N.W.I.

\section{The Royal Institution Library}

The Library of the Royal Institution, which contains about 65,000 volumes, is divided into five sections, comprising the old library-started in 1799 and including many of the early works of the great philosophers as well as books published up to 1857 and the notebooks, letters and papers of Count Rumford, Humphry Davy, Michael Faraday, John Tyndall and others ; the modern library--containing books published after 1857, arranged by the Gliss classification; the lending library, devoted mainly to general and popular science; the periodicals, of which 400 are currently received; and the storerooms. Notes on the library and its catalogues, with a list showing the holdings of periodicals and serial publications currently received, are given in a pamphlet recently issued (pp. 28. London: Royal Institution, 1958).

\section{Florida State Museum}

The Florida State Museum sorves as a joint University-State Museum and its major functions are to assemble and maintain collections of cultural and natural objects; to encourage research on this material; and to disseminate knowledge by publications and display. The annual report for 1957-58 (pp. 20. Gainesville, Fla. : Florida State Museum, The University, 1959) indicates that these functions have been fully maintained. During the period under review the staff has concentrated on the improvement of display, and many new ideas and techniques, especially those including the effect of artistry in presentation, have been incorporated. The investigation of archæological sites that might have been damaged by road construction has continued.

\section{Tetrahedron Letters}

As a supplement to the journal of organic chomis. try, Tetrahedron, the Pergamon Press (London and New York) has begun to issue fortnightly or monthly Tetrahedron Letters, in which short communications of interest to organic chemists will be published within a week or month of acceptanco (subscription, post paid (air mail charges extra) : $£ 7$ or 20 dollars per annum for libraries, government departments and industrial establishments; no extra charge for private subscribers to Tetrahedron who write direct to the publisher certifying that the subscription is for their personal use). The first number (pp. 35) was published in March and contains six short communications of an international character. This publication should relieve some of the pressure on othor scientific journals and its high standard seems likely to ensure it the success it deserves.

\section{Education of Instrument Technologists and Control Engineers}

THE subject of Mr. J. F. Coales's presidential address on May 6 to the Society of Instrument Technology was well chosen. Having shown the growing need for larger numbers of control engineers and instrument technologists and having proved that in most industries to-day there is some form of automatic control, he proceeded to outline the types of courses suitable for the men in charge. His views on the education of control engineers coincide with those expressed by several speakers at the conference on Degree and Diploma Courses in Applied Physics, arranged by the Society of Instrument Technology in November 1956, particularly in his insistence upon a broad-based fundamental approach for the graduate. Appendixes to his address contained valuable information which could not be easily assimilated into the body of the address, and many will bo particularly interested in Appendix 2, conccrned with detecting elements, and Appendix 3, outlining syllabuses for the ordinary National Certificate in Instrument Technology. Appendix 2 contains some twenty-one examples out of more than two hundred listed in a recent report on "Detecting Elements" published by the British Scientific Instrument Research Association.

\section{Cyanamid International : Technical Papers}

CERTAIN technical papers prepared by the research workers of Cyanamid for presentation before various learned socioties in the United States or for publication in the proceedings of technical institutions in that country are to be made available in Britain. These papers cover a wide range of subjects but fall roughly into three classifications: pharmaceutical, agricultural and industrial, these being the main spheres of activity in which the Cyanamid group of companies is engaged. From time to time lists are prepared showing details of the technical papers available for distribution. Readers who would like to receive these lists as and when they are issued should write to: Cyanamid International Information Service, 16 Bolton Street, London, W.1.

\section{The Age of the Earliest Remains of Man}

Certarn skeletal finds from caves in the dolomite formation of the Transvaal not far from Pretoria have been known for somo time. Whethor these are indeed the earliest known remains of true man or whether they must be considered as still prehuman romains a matter of controversy. The late Dr. van Riet Lowe described in Nature $(175,16 ; 1955)$ a series of chipped stones which he considered to be artefacts, so that the beings in question were toolusing creatures. But grave doubts have been cast on Lowe's opinion and the objects in question may be natural products. Their association with the skeletal remains is more than uncertain, and they are probably later in age. Nevertheless, those skeletal finds are of capital importance, particularly to the physical anthropologist, and it is especially important that the cave deposits containing the remains of the Australopithecinæ should be accurately dated. A detailed investigation by C. K. Brain has recently been published (The Transvaal Ape-Man - bearing Cave Deposits. By C. K. Brain, with an appendix by R. F. Ewer. Transvaal Museum Memoir No. 11. Pp. viii +131 . Pretoria : Transvaal Museum, 1958). The book can be recommended as a elear, succinct 